\title{
Model bimbingan dan konseling karier untuk mengatasi pengangguran di Kota Bogor
}

\author{
Putri Ria Angelina*, Rusdi Kasman \& Reni Sinta Dewi \\ Universitas Ibn Khaldun, Bogor \\ *putri@uika-bogor.ac.id
}

\begin{abstract}
This study aimed to determine the effect of career guidance and counseling program models in helping students to improve career maturity so that they could take the right career decisions and minimize the unemployment rate. As a result of the search, most of the unemployed in Indonesia came from high school graduates who were not ready to work in the industrial sector both in terms of skills and knowledge. Unemployment was also caused by a mismatch between majors studied with jobs and ideals, including a lack of information regarding the jobs or study program chosen. Students who were indicated to have low career maturity could be given intervention in career guidance and counseling program. The research used research and development methods involving Guidance and Counseling experts and students from high schools. Based on research results, the Career Guidance and Counseling program model was effective in increasing career maturity in which there were learning materials on self-knowledge, career orientation, and career planning. This is evidenced by the results of statistical data processing showing the sig. value of 0.000 was smaller than 0.05 at $5 \%$ significance level, so HO was rejected and Ha was accepted, resulting in this career guidance and counseling program indirectly contributed to reducing unemployment
\end{abstract}

Keywords: career; guidance and counseling; unemployment

\begin{abstract}
Abstrak
Penelitian ini bertujuan untuk mengetahui pengaruh model program bimbingan dan konseling karier dalam membantu peserta didik meningkatkan kematangan karier sehingga dapat mengambil keputusan karier yang tepat dan bisa meminimalisasi angka pengangguran. Sebagaimana hasil penelusuran, bahwa sebagian besar pengangguran yang terjadi di Indonesia berasal dari lulusan SMA sederajat yang tidak siap pakai didunia industri baik dari segi keterampilan dan pengetahuan. Pengangguran juga disebabkan oleh ketidaksesuaian antara jurusan dengan pekerjaan dan cita-cita, termasuk kurang informasi terkait pekerjaan atau program studi yang dipilih. Peserta didik yang terindikasi memiliki kematangan karier yang rendah, dapat diberikan intervensi berupa program bimbingan dan konseling karier. Metode penelitian menggunakan research and development melibatkan pakar Bimbingan dan Konseling (BK) serta peserta didik dari SMA sederajat. Berdasarkan hasil penelitian, model program Bimbingan dan Konseling Karier efektif meningkatkan kematangan karier yang di dalamnya terdapat materi mengenal potensi diri, orientasi karier dan perencanaan karier. Hal ini dibuktikan oleh hasil olah data statistik menunjukkan nilai sig. 0.000 lebih kecil dari 0.05 pada taraf signifikansi 5\% maka H0 ditolak dan Ha diterima, sehingga secara tidak langsung program bimbingan dan konseling karier ini berkontribusi menekan angka pengangguran.
\end{abstract}

Kata kunci: bimbingan dan konseling; karier; pengangguran

Diserahkan: 19-09-2020 Disetujui: 30-09-2020. Dipublikasikan: 01-10-2020

Kutipan: Angelina, P., Kasman, R., \& Dewi, R. (2020). Model bimbingan dan konseling karier untuk mengatasi pengangguran di Kota Bogor. Ta'dibuna: Jurnal Pendidikan Islam, 9(2), 178-192.

doi:http://dx.doi.org/10.32832/tadibuna.v9i2.3442 


\section{Pendahuluan}

Indonesia dalam menghadapi siklus ekonomi yang masih berada pada kondisi tidak stabil perlu adanya dukungan dari berbagai pihak, mulai dari pemerintah, sektor penyedia lapangan pekerjaan serta sektor pendidikan. Khususnya pada sektor pendidikan erat kaitannya dengan program bimbingan dan konseling (BK) yang berupaya memberikan pemahaman karier bagi peserta didik. Hal ini menjadi tantangan tersendiri bagi layanan bimbingan dan konseling di sekolah pasalnya tingkat pengangguran di Indonesia masih berada pada tingkat tinggi. Terlebih lagi pada masa pandemi covid-19 yang mengharuskan seseorang agar lebih mahir dalam menggali inovasi dan kreativitasnya demi keberlangsungan hidup.

berdasarkan data yang berhasil dicatat oleh Badan Pusat Statistik (BPS) menunjukkan bahwa per Februari 2020 angka pengangguran di Indonesia mencapai 6,82 juta orang. Persentase pengangguran terbanyak didominasi oleh lulusan Sekolah Menengah Kejuruan (SMK) yaitu sebayak 8,49 persen, diikuti oleh lulusan SMA sebanyak 6,77 persen, kemudian lulusan diploma sebanyak 6,76 persen, lulusan sarjana sebanyak 5,73 persen, lulusan SMP sebanyak 5,02 persen dan pada jenjang pendidikan SD ke bawah sebanyak 2,64 persen. Jika ditinjau berdasarkan usia, maka penduduk dengan usia muda (15-24 tahun) dinilai masih tinggi tingkat pengangguran terbukanya, sedangkan pada usia 25-59 tahun dan 60 tahun ke atas mengalami penurunan dibandingkan tahun sebelumnya (Kencana, 2020).

Bonus demografi Indonesia akan berada dipuncaknya antara tahun 2020 sampai 2030. Saat ini usia produktif (15 sampai 35 tahun) berada sebanyak 34 persen dari seluruh masyarakat Indonesia. Mereka inilah yang akan menumbuhkan pertumbuhan ekonomi Indonesia. (Adioetomo, 2010)

Sekolah menjadi institusi yang mempersiapkan pemenuhan sumber daya manusia (SDM) yang berkualitas dan kompetitif sebagai generasi penerus bangsa. Hal ini sebagaimana yang tercantum dalam undang-undang No. 20 tahun 2003 yang menjelaskan bahwa tujuan pendidikan nasional adalah untuk mengembangkan potensi peserta didik agar menjadi individu yang bertakwa kepada Tuhan yang maha esa, berilmu, kreatif, dan mandiri. Sebagai upaya mencapai tujuan tersebut, sekolah telah merancang kurikulum, metode pembelajaran hingga perlengkapan media lainnya.

Sekolah memiliki peranan penting bagi perkembangan intelektual, keterampilan sosial serta dunia karier yang ingin di tekuni oleh peserta didik. Namun selain fokus pada perkembangan intelektual, sosial dan karier siswa, sekolah juga harus memperhatikan perkembangan remaja. Masa remaja menjadi suatu fase yang penting bagi masa perkembangan selanjutnya. Karena pada masa ini remaja mulai berusaha menentukan jati diri, mencapai kemandirian emosional, kematangan hubungan sosial dan mencapai kematangan karier (Hurlock, 2010). 
Sekolah merupakan institusi sebagai penjabaran undang-undang di atas yang di dalamnya tempat mempersiapkan dan mewujudkan sumber daya manusia (SDM) yang berkualitas dan memiliki keunggulan kompetitif yang akan menjadi generasi penerus bangsa. Hal ini dapat dipahami karena sekolah mempunyai tujuan dan perencanaan yang jelas, dapat dilihat dengan adanya kurikulum, metode, media pendidikan dan lain-lain. Hurlock menjelaskan bahwa sekolah memegang peranan sangat penting bagi perkembangan intelektual, keterampilan sosial dan menunjang dunia kejuruan yang ingin di masuki. Selain mengembangkan kapasitas intelektual, sosial dan kejuruan, sekolah juga memberikan pengaruh cukup besar bagi perkembangan remaja. Masa remaja adalah masa yang sangat penting bagi perkembangan pada masa-masa selanjutnya, karena masa remaja menjadi dasar bagi berhasil atau tidaknya seseorang menjalani kenyataan hidup pada perkembangan selanjutnya. Pada masa ini remaja berusaha untuk menentukan jati diri, mencapai kemandirian emosional, kematangan hubungan sosial, dan mempersiapkan diri meniti karier.

Bagi siswa dalam menentukan karier bukan perkara yang mudah, butuh kesiapan dan kematangan dalam menentukan pilihan yang sesuai dengan bakat dan keterampilan yang dimiliki. Kemampuan untuk mempersiapkan karier sebaiknya telah tumbuh sejak seseorang menginjak masa remaja, karena pada masa remaja merupakan masa transisi menuju dewasa. Mempersiapkan diri untuk bekerja dan berkarir merupakan salah satu ciri masuknya seseorang dalam menjalankan gaya hidup orang dewasa (adult life style).

Karier bagi siswa bukan hal yang mudah untuk ditentukan dan menjadi pilihan yang sesuai dengan kemampuan yang dimiliki namun haruslah ditentukan. Persiapan diri dan pemilihan dalam menjalankan suatu pekerjaan atau karier merupakan salah satu tugas perkembangan yang penting di masa remaja. Masa remaja merupakan masa transisi menuju ke masa dewasa, begitu juga halnya dalam berkarir. Bekerja atau berkarir sendiri merupakan salah satu penanda masuknya seseorang ke dalam gaya hidup orang dewasa (adult life style).

Penentuan karier didasarkan pada keputusan siswa berdasarkan pemahaman tentang kemampuan, minat dan bakat serta pengenalan karier yang ada di masyarakat. Dewasa kini masih banyak ditemui siswa pada usia remaja yang merasa kesulitan dalam memilih dan menentukan karier sebagai salah satu usaha dalam mencapai kehidupan yang lebih baik dimasa mendatang. Serta beranggapan bahwa pemahaman karier bukan suatu hal yang perlu direncanakan sejak dini. (Yumnah, 2016)

Untuk menentukan hal demikian harus didasarkan pada keputusan siswa itu sendiri yang didasarkan pada pemahaman tentang kemampuan dan minat serta pengenalan karier yang ada di masyarakat. Kesulitan yang dialami siswa dalam memilih dan menentukan karier tidaklah dapat dipungkiri, masih ada siswa yang kurang memahami bahwa karier merupakan jalan hidup dalam usaha menggapai kehidupan yang baik 
dimasa mendatang. Juga menganggap bukanlah suatu hal yang harus direncanakan sejak dini.

Sebelumnya peneliti telah melakukan pra-penelitian dengan melakukan survei kepada guru Bimbingan dan Konseling (BK) pada tingkat SMA sederajat di kota Bogor untuk mendapatkan data terkait permasalahan karier yang dihadapi oleh siswa. Beberapa permasalahan karier yang ditemui adalah: 1) pemahaman siswa tentang kelanjutan pendidikan setelah lulus masih terbatas, 2) siswa belum bisa memahami jenis pekerjaan yang cocok dan sesuai dengan kemampuan dirinya, 3) masuk pada program studi yang bukan pilihannya sendiri, 4) siswa merasa kurang percaya diri dalam menentukan karier yang dengan kemampuan sendiri.

Beberapa permasalahan karier peserta didik yang menggejala saat ini berdasarkan survei kepada guru Bimbingan dan Konseling (BK) tingkat SMA sederajat di Kota Bogor adalah: (1) belum memiliki pemahaman yang mantap tentang kelanjutan pendidikan setelah lulus, (2) program studi yang dimasuki bukan pilihan sendiri, (3) belum memahami jenis pekerjaan yang cocok dengan kemampuan sendiri, (4) masih bingung untuk memilih karier yang sesuai dengan minat dan kemampuan.

Penelitian terhadap mahasiswa jurusan Ilmu Sosial dan Politik Universitas Airlangga menunjukkan bahwa alasan mahasiswa memilih program studi ini adalah: sebanyak 52,77 persen beralasan karena mudah ditembus, dan sebanyak 31,11 persen beralasan karena sesuai dengan minat. Hal ini menunjukkan bahwa pemahaman karier mahasiswa masih belum maksimal dan belum memahami bahwa usia dan minat dapat memberikan pengaruh terhadap kehidupan (Intani \& Surjaningrum, 2010). Permasalahan pemilihan program studi yang bukan atas keinginan sendiri cenderung membuat individu tidak nyaman dalam belajar sehingga berdampak pada raihan nilai akademis, pindah jurusan atau bahkan hingga drop out. Hal ini juga sama dirasakan oleh siswa SMK, SMA ataupun MA yang merasa mengalami kekeliruan saat pemilihan sekolah (Masriah, Malay, \& Fitriani, 2018).

Orientasi karier merupakan akar dari permasalahan karier, salah satunya adalah pengangguran. Maka orientasi karier yang tepat akan memberikan kontribusi besar dalam perjalanan pendidikan dan pekerjaan nantinya. Termasuk peserta didik yang berada pada jenjang SMA sederajat (Crites, 1976).

Salah satu tugas perkembangan pada usia remaja adalah mampu mempersiapkan diri merencanakan karier. Sehingga individu sejak menginjak usia remaja harus sudah mampu menentukan karier untuk ditekuni dan mempersiapkan diri dengan mengikuti pendidikan atau mengasah keterampilan yang relevan dengan karier yang dipilih. Sebagai upaya persiapan individu memilih dan merencanakan karier secara tepat, dibutuhkan pencapaian kematangan karier yang terdiri atas pengetahuan tentang diri, 
pengetahuan tentang pekerjaan, serta kemampuan untuk merancang rencana dan langkah menuju karier yang diharapkan (Hurlock, 2010).

Senada dengan Hurlock, Ginzberg menambahkan bahwa pada usia SMA sederajat, pilihan karier seseorang akan mengalami perkembangan. Hal ini berkaitan dengan semakin tingginya pemahaman dan pengalaman individu. Berawal dari pertimbangan karier berdasarkan ketertarikan, kesenangan ataupun minat tanpa mempertimbangkan faktor lain. Kemudian perlahan akan muncul kesadaran bahwa minat individu dapat berubah-ubah hingga muncul pertanyaan anak terhadap dirinya tentang apa kemampuan dan kapasitas yang ia miliki? Apakah kemampuan dan kapasitas tersebut sesuai dengan karier yang diminati?. Untuk menjawab hal ini tentu perlu adanya orientasi dan pemahaman dan kematangan karier. Karena rendahnya kematangan karier bisa jadi penyebab kesalahan dalam pengambilan keputusan termasuk dalam menentukan pendidikan lanjutan (Crites, 1976)

Sementara itu kaitannya dengan kematangan karier, Crites menjelaskan bahwa kematangan karier ditandai dengan meningkatnya kesiapan seseorang dalam menentukan karier, dan kesiapan ini akan terus meningkat seiring dengan usianya. Dalam temuannya, ia mengelompokkan dua aspek kematangan karier yang telah diturunkan dalam inventori kematangan karier. Kedua aspek tersebut di antaranya adalah: 1) Aspek Kognitif, meliputi (a) Penilaian diri, yaitu berupa penilaian terhadap sifat dan kecenderungan hipotesis individu dalam hubungannya dengan keberhasilan dan keputusan karier, (b) Informasi, yaitu berupa pengetahuan tentang syarat- syarat dalam pekerjaan, pendidikan atau pelatihan dll., (c) Seleksi tujuan, yaitu berupa nilai-nilai periodik yang ingin dicapai dalam pekerjaan, (d) Perencanaan, yaitu berupa perencanaan langkah yang logis dalam proses pengambilan keputusan karier, (e) Pemecahan masalah, yaitu bagaimana individu dapat mencari solusi dalam pengambilan keputusan karier. 2) Aspek Afektif, meliputi: (a) Keterlibatan untuk mengukur sejauh mana individu terlibat dalam pengambilan keputusan, (b) Independensi, merupakan tingkat kemandirian individu dalam proses pengambilan keputusan, (c) Orientasi untuk mengetahui tingkat orientasi terhadap karier yang diminati, apakah orientasinya lebih mengarah pada kesenangan atau pekerjaan, (d) Ketegasan, yaitu sikap individu dalam memastikan pilihan karier, (e) Kompromi untuk mengukur sejauh mana individu menjalin kompromi yang berkaitan dengan keadaan diri sendiri (Crites, 1976).

Masih menurut Crites, melalui penelitiannya menjelaskan bahwa dalam rangka menetapkan orientasi karier maka perlu ada kesiapan individu untuk membuat keputusan karier yang tepat. Pada orientasi karier terdiri dari tiga dimensi, yaitu: 1) career development attitudes (sikap terhadap karier) yaitu tentang kecenderungan dalam berperilaku, bertindak dan memberikan persetujuan terhadap suatu pilihan atau arah kecenderungan individu dalam menetapkan pilihan bidang karier. Sikap individu 
terhadap kecenderungan karier dapat dianalisis melalui perencanaan karier (career planing) dan eksplorasi karier (career exloration). 2) skills of carrer development decision making yaitu keterampilan dalam membuat keputusan karier. Konsep keterampilan dalam karier mengacu pada penggunaan pengetahuan, dan pemikiran dalam membuat keputusan karier. 3) world-of-work information yaitu terkait informasi dalam dunia kerja yang meliputi informasi tentang pekerjaan tertentu dan informasi terkait orang lain yang terlibat dalam pekerjaan tersebut. (Crites, 1976)

Kaitannya dengan jumlah pengangguran, bertambahnya jumlah pengangguran dipicu oleh rendahnya orientasi di masa depan. Hal ini disebabkan oleh rendahnya pengetahuan atau informasi yang diperoleh mahasiswa sehingga perlu dipahami bahwa dalam upaya memahami diri sendiri tidak mudah dan tidak akan muncul dengan sendirinya jika individu tersebut tidak berusaha.

Selanjutnya penelitian Novia Rohmawati menunjukkan bahwa kemandirian siswa dalam merencanakan karier berada pada kategori tinggi yaitu $(M=188,14)$, dan persepsi siswa terkait layanan bimbingan karier masuk pada kategori sangat tinggi yaitu $(M=194,32)$. Dengan demikian menunjukkan bahwa jika persepsi siswa tentang layanan bimbingan dan konseling karier positif maka tingkat kemandirian siswa dalam merencanakan karier juga akan tinggi. Sehingga guru Bimbingan dan Konseling harus memberikan layanan yang sesuai dengan kebutuhan siswa supaya dapat membantu meningkatkan kemandirian siswa dalam merencanakan karier (Rohmawati, 2019).

Kaitannya dengan layanan bimbingan karier, penelitian Istirahayu menunjukkan bahwa terdapat pengaruh positif sebesar 0,098 antara pemberian layanan bimbingan karier terhadap keputusan pemilihan studi lanjut siswa kelas XII. Oleh karena itu pelaksanaan layanan bimbingan dan konseling karier disekolah harus dirancang semaksimal mungkin agar dapat membantu siswa dalam menetapkan pengambilan keputusan terkait studi lanjut yang sesuai dengan minat dan kemampuan yang dimiliki. (Istirahayu, Mayasari, Fitriyadi, \& Damayanti, 2018)

Berdasarkan beberapa uraian di atas, maka penelitian ini berupaya untuk menghasilkan sebuah landasan terhadap program bimbingan dan konseling karier di jenjang SMA sederajat dengan melaksanakan kegiatan layanan bimbingan dan konseling karier yang akan membantu peserta didik dalam mengenali diri, melakukan orientasi karier hingga tahap perencanaan karier yang seharusnya. Terkait materi yang disiapkan antara lain pengenalan diri, orientasi karier dan perencanaan karier. Sehingga melalui landasan program bimbingan dan konseling ini diharapkan dapat mengurangi risiko pengangguran di Indonesia.

\section{Metode Penelitian}


Metode yang digunakan dalam penelitian ini adalah metode deskriptif analitis yaitu studi yang digunakan untuk mengumpulkan data, mendeskripsikan, mengolah, menganalisis, menyimpulkan dan menafsirkan data sehingga diperoleh gambaran yang sistematis.

Penelitian ini menggunakan metode research and development yaitu penelitian pengembangan dalam menguji suatu produk. Adapun produk yang dimaksud dalam penelitian ini model program bimbingan dan konseling karier untuk menekan angka pengangguran.

Pada penelitian ini, metode penelitian research and development menggunakan model Borg dan Gaal dalam (Sugiyono, 2014) dengan perincian sebagai berikut:

1. Penelitian pendahuluan, meliputi analisis kebutuhan, studi literatur.

2. Pengembangan desain (develop preliminary of product) mencakup desain model bimbingan dan konseling karier dengan melibatkan pakar bimbingan dan konseling karier.

Langkah dalam penelitian ini melalui tiga tahap, yaitu: [1] Tahap studi pendahuluan: Mengumpulkan data terkait kebutuhan siswa serta gambaran umum program bimbingan dan konseling di sekolah serta mengumpulkan data literatur terkait program layanan bimbingan dan konseling karier. [2] Tahap Pengembangan: didahului oleh uji coba lapangan awal (preliminary field testing) yang dilakukan di Kota Bogor. Uji coba ini didahului dengan (pelatihan guru BK). Kemudian dilanjutkan pada tahap persiapan uji coba, meliputi penentuan sasaran siswa, waktu dan tempat pelaksanaan. [3] Tahap Validasi yaitu pelaksanaan uji coba, dan evaluasi uji coba. Tujuan utama tahap validasi adalah untuk menyimpulkan kelayakan model untuk digunakan secara umum.

Lokasi penelitian dilaksanakan di SMA/SMK Kota Bogor. Subjek penelitian melibatkan delapan orang pakar Bimbingan dan Konseling serta 160 peserta didik dari jenjang SMA/SMK (10 peserta didik untuk uji coba dan 150 peserta didik untuk penelitian). Sampel penelitian delapan orang pakar Bimbingan dan konseling dipilih berdasarkan keahlian pada bidangnya. Sedangkan penentuan sampel sebanyak 160 peserta didik dilakukan secara random. Adapun waktu pelaksanaan penelitian ini berlangsung dari bulan Maret s.d Agustus 2020.

Teknik pengumpulan data yang digunakan: (1) Wawancara. Menurut Lexy J Moleong (2005), wawancara adalah suatu percakapan dengan tujuan/maksud tertentu. Teknik wawancara dilakukan untuk memperoleh gambaran tentang layanan bimbingan dan konseling karier yang selama ini digunakan khususnya di sekolah. Adapun narasumber yang ditunjuk adalah guru bimbingan dan konseling di SMA dan SMK Kota Bogor. (2) Observasi, merupakan suatu metode pengumpulan data yang digunakan untuk data penelitian sesuai dengan tema yang akan diamati. Pada penelitian ini observasi yang 
dilakukan adalah mengamati respons anak terkait dengan bimbingan dan konseling karier. (3) FGD (forum group discussion), dilakukan untuk merumuskan konsep awal dan akhir.

Uji validitas pada penelitian ini menggunakan uji kredibilitas (validitas interval) dengan fokus pada metode triangulasi. Menurut Moleong (2005), triangulasi merupakan salah satu teknik pengujian keabsahan data yang diperoleh dengan memanfaatkan sesuatu/ orang lain sebagai sumber untuk keperluan pengecekan data ataupun pembanding terhadap data yang telah diperoleh dari responden. Jenis triangulasi yang digunakan pada penelitian ini adalah triangulasi sumber, yaitu melakukan crosscheck data yang telah diperoleh kepada sumber lain yaitu guru BK dan para ahli bimbingan dan konseling. Metode analisis data dalam penelitian ini menggunakan teknik analisis deskriptif dan diperkuat oleh uji statistik (uji t) untuk mengetahui apakah ada perbedaan antara sebelum dan sesudah menggunakan model bimbingan dan konseling karier.

\section{Hasil dan Pembahasan}

Pada saat melakukan analisis kebutuhan, peneliti menemukan bahwa sebagian besar peserta didik merasa kebingungan akan memilih kegiatan apa setelah lulus dari SMA sederajat. Apakah mereka akan melanjutkan dengan bekerja ataukah berkuliah yang mereka juga bingung akan mengambil jurusan apa. Data yang terungkap menunjukkan bahwa pengangguran di Indonesia saat ini sebagian besar berlatar belakang SMK sederajat. Selain itu, didapatkan data bahwa sebagian besar peserta didik yang bingung akan melanjutkan ke mana setelah SMA/SMK, dikarenakan mereka tidak mengetahui apa sesungguhnya potensi yang ada pada diri mereka. Peserta didik juga tidak memiliki pengetahuan dan sikap yang cukup luas sebagai bekal dalam mengambil keputusan karier setelah lulus SMA.

Oleh karena itu, peneliti melakukan pengembangan desain (develop preliminary of product) mencakup desain model bimbingan dan konseling karier dengan melibatkan pakar bimbingan dan konseling karier. Peneliti melakukan Focus Group Discussion (FGD) dengan Guru Bimbingan dan Konseling (BK) terkait dengan program BK karier yang ada disekolah mereka masing-masing termasuk kendala dalam pelaksanaannya juga permasalahan karier yang dihadapi oleh peserta didik.

Setelah mempelajari studi literatur peneliti melaksanakan FGD dengan pakar BK yang menyatakan bahwa program bimbingan dan konseling karier memadai untuk dilaksanakan. Namun terdapat beberapa masukan, antara lain: siswa diberikan layanan terkait materi tentang kreativitas, pengenalan potensi diri, menanamkan jiwa kewirausahaan sejak dini, memberikan pemahaman bahwa karier bukan hanya bekerja saja tapi bisa tentang menciptakan lapangan pekerjaan dan akan lebih baik jika terdapat kerja sama antara sekolah dan perusahaan. Selanjutnya peneliti membuat model 
bimbingan dan konseling karier yang membagi menjadi 3 materi besar yaitu pengenalan potensi diri, orientasi karier, dan perencanaan karier dan dibagi menjadi 3 (tiga) sesi dengan masing-masing durasi 40 menit. Adapun pelaksanaan melalui grup Whatsapp dengan cara pemberian materi berupa File PDF, File berbentuk gambar (JPEG) dan file berupa audio. Setiap sesi, para siswa memberikan umpan balik dengan mengisi kuesioner yang sudah diberikan.

Sesi pertama Pengenalan Potensi Diri. Kegiatan pertama yang dilakukan peneliti adalah membangun raport (perkenalan dan membangun kehangatan) kepada peserta didik. Selanjutnya peneliti membagikan kuesioner untuk mendapatkan data awal (pretest) tentang tingkat kematangan karier peserta didik. Peneliti kemudian memberikan informasi tentang pentingnya mengenal diri. Peserta didik diminta untuk menuliskan bakat, minat, keterampilan yang di miliki. Jika peserta didik telah memiliki hasil tes bakat, minat, maka mereka diminta untuk membaca dan menelaah bersama hasil yang mereka miliki. Peserta didik perlu mengetahui potensi, kelebihan dan kekurangan diri untuk menjadi pijakan dalam membuat perencanaan karier.

Pada sesi kedua, pemberian layanan dasar untuk membantu peserta didik membuat keputusan karier terletak pada orientasi karier. Adapun hal yang dibahas pada sesi ini adalah sikap karier peserta didik, keterampilan peserta didik membuat keputusan karier, informasi kepada peserta didik terkait dunia kerja.

Materi Sesi ketiga yaitu Perencanaan Karier. Peserta diminta untuk membuat perencanaan setelah lulus SMA/SMK. Jika dia ingin kuliah, dia mempertimbangkan potensi diri dia dengan jurusan atau program studi yang ingin di ambil. Jika dia ingin bekerja, maka menuliskan rencana akan bekerja di mana sesuai dengan potensi yang ada pada dirinya dan target dalam 2-5 tahun ke depan. Peserta diminta mempresentasikan dan menerima masukan dari pihak lain.

Pengisian kuesioner kematangan karier peserta didik dilakukan untuk melihat sejauh mana pengetahuan dan keterampilan mereka dalam mengambil keputusan karier. Adapun hasil yang di dapatkan adalah hasil dari uji coba program dan hasil dari penelitian setelah revisi program yang diujicobakan.

Untuk uji coba, diberikan kepada 10 orang responden. Hasil dari pengisian sebelum kegiatan layanan diberikan, responden yang berjumlah sepuluh orang memiliki tingkat kematangan karier yang bervariasi. Kematangan karier kategori sedang dimiliki oleh 2 responden sedangkan 8 orang sisanya berada pada tingkat kematangan karier rendah. Responden yang berada pada kategori rendah sebagian besar kurang matang pada kategori potensi diri dan perencanaan karier. Responden merasa kesulitan membaca potensi diri dan kurang mampu mengaitkan potensi diri dalam perencanaan karier yang akan mereka buat dan keputusan yang akan mereka ambil. 
Setelah program bimbingan dan konseling karier dilaksanakan, kembali di berikan kuesioner kematangan karier untuk mengukur kemampuan mereka dalam mengambil keputusan karier. Hasil yang didapatkan adalah, 8 (delapan) orang responden berada pada kategori tinggi dan 2 (dua) orang berada pada kategori sedang. Berdasarkan hasil penelitian ini, maka bisa didapatkan kesimpulan bahwa pelaksanaan program bimbingan dan konseling karier dengan 3 (tiga) materi yaitu pengenalan potensi diri, orientasi karier dan perencanaan karier, bisa membantu peserta didik memiliki kematangan karier yang baik sebagai modal dalam perencanaan karier mereka dan pengambilan keputusan karier mereka. Responden semakin paham cara membaca potensi diri dan cara mengaitkannya dalam keputusan karier yang akan diambil ketika lulus dari SMA/SMK sederajat.

Setelah melakukan uji coba, peneliti melakukan revisi program berdasarkan masukan dari angket yang telah dibagikan dan FGD bersama pakar BK untuk dilaksanakan pada program penelitian selanjutnya. Adapun masukan yang dapat disimpulkan antara lain: untuk materi sesi 1 perlu ditambahkan materi tentang kepercayaan diri agar siswa merasa percaya diri ketika mengambil keputusan untuk kariernya. Selain itu, materi pendukung yang disarankan untuk disampaikan yaitu memberikan arahan kepada siswa yang memiliki potensi namun memiliki kondisi kurang mampu (misal : informasi beasiswa, dll.). Pada sesi kedua masukan yang diberikan antara lain materi gambaran nyata dunia kerja baik dari penjelasan bidang karier, gambaran salary dari setiap bidang, sehingga siswa dapat menentukan pilihan karier yang sesuai dengan potensi yang dimiliki. Selanjutnya sesi ketiga adalah komunikasi antara anak dan orang tua dalam memutuskan pilihan karier, baik dalam hal memilih pekerjaan atau melanjutkan ke jenjang pendidikan yang lebih tinggi. Selain itu, jika perencanaan karier sudah dibuat, agar siswa konsisten dengan impiannya, terdapat masukan dari guru BK agar siswa mengabadikan planning career di sosial media. Adapun pada penelitian yang diberikan setelah program di revisi, penelitian diikuti oleh 150 responden dari berbagai latar belakang SMA sederajat. Adapun hasil yang didapatkan adalah penelitian memiliki efektivitas untuk meningkatkan kematangan karier peserta didik yang telah memiliki perencanaan yang matang setelah lulus dari SMA sederajat.

Tabel 1. Paired Samples Test

\begin{tabular}{|c|c|c|c|c|c|c|c|c|c|}
\hline & & \multicolumn{5}{|c|}{ Paired Differences } & \multirow{3}{*}{$\mathbf{t}$} & \multirow{3}{*}{ df } & \multirow{3}{*}{$\begin{array}{l}\text { Sig. (2- } \\
\text { tailed) }\end{array}$} \\
\hline & & \multirow[t]{2}{*}{ Mean } & \multirow[t]{2}{*}{$\begin{array}{c}\text { Std. } \\
\text { Deviation }\end{array}$} & \multirow[t]{2}{*}{$\begin{array}{l}\text { Std. } \\
\text { Error } \\
\text { Mean }\end{array}$} & \multicolumn{2}{|c|}{$\begin{array}{l}\text { 95\% Confidence } \\
\text { Interval of the } \\
\text { Difference }\end{array}$} & & & \\
\hline & & & & & Lower & Upper & & & \\
\hline Pair 1 & $\begin{array}{l}\text { sebelum - } \\
\text { sesudah }\end{array}$ & -7.8933 & 4.7658 & .38913 & -8.6622 & -7.1244 & -20.285 & 149 & .000 \\
\hline
\end{tabular}


Dari tabel 1, dapat disimpulkan karena nilai sig. 0.000 lebih kecil dari 0.05 maka tolak H0, cukup bukti untuk menyatakan bahwa terdapat perbedaan yang signifikan antara sebelum dan sesudah pada taraf nyata $5 \%$.

Layanan informasi karier sangat penting adanya terutama pada lembaga pendidikan formal. Tidak sedikit dijumpai siswa yang merasa bingung dan bimbang dalam hal menentukan pilihan dan keputusan perihal karier. Sebagaimana hasil penelitian Richma Hidayati yang menunjukkan bahwa masih banyak peserta didik yang merasa kesulitan dalam memahami diri yang berhubungan dengan perencanaan karier dan keputusan karier. Sehingga hal ini berdampak pada kemampuan siswa untuk mencapai tujuan dan cita-cita yang diharapkan. Sebagai upaya meminimalisasi keadaan tersebut maka layanan informasi karier dirasa sangat penting diberikan kepada siswa baik pada tingkat SMP maupun SMA sederajat. Kesulitan-kesulitan dalam mengambil keputusan dapat dihindari ketika siswa memiliki sejumlah informasi yang memadai terkait dengan jenjang pendidikan atau dunia kariernya (Hidayati, 2015b).

Kaitannya dengan permasalahan karier, Hartinah dan Wibowo dalam penelitiannya mengembangkan model layanan informasi karier berbasis life skill yang terbukti efektif meningkatkan pemahaman dalam perencanaan karier siswa khususnya pada tingkat SMA. Adapun desain model yang dikembangkan dalam layanan informasi karier berbasis life skill terdiri dari enam komponen, yaitu rasional, visi dan misi layanan informasi karier, tujuan layanan informasi karier, isi layanan informasi karier dan tahapan layanan informasi karier berbasis life skills. Pemahaman dan perencanaan karier dapat diintegrasikan dengan nilai-nilai yang terkandung dalam kecapan hidup yang meliputi kecakapan personal, sosial, akademik dan vokasional. Dengan demikian siswa lebih mudah dalam memahami tentang potensi diri, bakat, minat dan keterampilan diri, memiliki pemahaman dalam berinteraksi dan bekerja sama dengan orang lain serta memiliki pandangan terkait rencana studi lanjut dan keterampilan dalam bekerja (Hartinah \& Wibowo, 2015).

Lain halnya dengan Galuh, penelitian Afdal dkk. menggunakan layanan bimbingan dan konseling karier kolaboratif sebagai upaya pemantapan perencanaan karier. Adapun layanan bimbingan dan konseling kolaboratif yang dimaksud adalah dengan melibatkan beberapa pihak untuk dapat bekerja sama dalam mengimplementasikan layanan bimbingan dan konseling karier agar terlaksana secara optimal. Beberapa pihak yang turut bekerja sama di antaranya adalah guru BK/Konselor, Guru mata pelajaran, dan orang tua. Indikator perencanaan karier yang mantap dapat dilihat pada beberapa aspek, di antaranya: 1) Pemahaman diri terkait dengan kecerdasan umum, kecerdasan khusus, keterampilan, minat, bakat, hobi, nilai-nilai kehidupan, prestasi yang diraih, cita-cita, sifat dan keadaan fisik. 2) Pemahaman terhadap lingkungannya, meliputi lingkungan keluarga, sekolah, masyarakat, pekerjaan. 3) Merumuskan pilihan berdasarkan tujuan 
yang ingin dicapai, mencari informasi terkait tujuan yang ingin dicapai baik dalam pekerjaan maupun studi lanjut. 4) Merumuskan rencana tindakan dengan mengikuti agenda/kegiatan dan rencana pendidikan lanjutan. Dengan demikian, layanan bimbingan dan konseling kolaboratif efektif digunakan untuk memberikan pemantapan karier bagi siswa (Afdal, Suya, Syamsu, \& Uman, 2014).

Sedangkan menurut Kadiyono, sebagai upaya menangani permasalahan karier pada siswa khususnya pada tingkat SMA/SMK adalah dengan pengembangan potensi diri dan orientasi wirausaha yang sangat penting dalam rangka meningkatkan sikap atau dorongan siswa supaya mampu berwirausaha secara mandiri. Namun untuk meraih sikap wirausaha yang baik tentu saja individu harus mengenali potensi diri dan memiliki motivasi dalam berprestasi. Sehingga melalui penelitiannya diperoleh hasil bahwa terdapat beberapa aspek yang turut berkontribusi dalam membangun sikap kewirausahaan, di antaranya adalah self esteem, achievement, innovation, dan personal control. Persentase self esteem di sini memberikan kontribusi paling rendah dibandingkan ketiga aspek lainnya, yaitu sebesar 0,227 sedangkan dimensi achievement $(0,324)$, innovation $(0,280)$, personal control $(0,283)$. Dengan demikian dapat ditarik simpulan bahwa pentingnya memahami potensi diri sebagai upaya menumbuhkan motivasi berwirausaha dan kemampuan menentukan karier (Kadiyono, 2014).

Selanjutnya Adiputra melalui penelitiannya menjelaskan pentingnya perencanaan karier untuk ditanamkan dan direncanakan sejak dini karena akan berpengaruh terhadap sikap bertanggungjawab dan diharapkan dapat meminimalisasi adanya penyimpangan terhadap tugas-tugas perkembangan individu. Hasil penelitian Sofwan membuktikan bahwa melalui bimbingan dan konseling kelompok dengan teknik modeling terbukti efektif meningkatkan perencanaan karier khususnya pada siswa kelas X SMA Yasmida Ambarawa (Adiputra, 215).

Sebuah penelitian menunjukkan bahwa berdasarkan data di lapangan yang diperoleh dari 5 SMA Negeri di Kabupaten Purbalingga, siswa yang melanjutkan studi ke perguruan tinggi maupun bekerja setelah lulus sekolah hanya sebesar 30-50\%. Angka tersebut menunjukkan bahwa orientasi karier siswa masih berada pada tingkat yang rendah/sedang. Berlandaskan data demikian, Yusuf Rudy Gunawan melalui penelitiannya membuktikan bahwa hubungan teman sebaya dan kondisi sosial ekonomi keluarga sangat berpengaruh terhadap orientasi karier siswa (Gunawan, 2017).

Peter menjelaskan bahwa terdapat beberapa faktor yang mempengaruhi individu dalam menentukan keputusan karier. Adapun beberapa faktor tersebut adalah: a) pengalaman sosial, b) keterlibatan dengan orang lain, c) potensi yang dimiliki oleh individu, d) dorongan orang tua dan keluarga, e) peminatan individu, f) informasi dan pemahaman terkait dunia kerja, g) pertimbangan terhadap pilihan/alternatif karier, h) keterampilan dalam membuat keputusan karier (Sukardi 1987). 
Setelah mengenal potensi diri yang dimiliki masing-masing individu, maka selanjutnya adalah merumuskan orientasi masa depan/karier. Menurut Nurmi (1987) menjelaskan bahwa dalam merumuskan orientasi masa depan/karier individu terbentuk melalui 3 aspek utama, yaitu: 1) Motivasi, berupa dorongan yang untuk melakukan sesuatu, 2) Perencanaan, yaitu menyusun langkah demi mencapai orientasi karier, 3) Evaluasi diri, yaitu mengukur kemampuan dan potensi yang dimiliki individu sesuai dengan orientasi karier yang dituju. (Nurmi, 1987)

Sedangkan hasil penelitian Eny menunjukkan terdapat beberapa aspek orientasi masa depan/karier, yaitu: 1) Evaluasi diri, yaitu mencari dan memahami informasi terkait karier/pekerjaan yang diminati, 2) Perencanaan, yaitu melihat kondisi keluarga, lingkungan dan emosi diri, 3) Memiliki rasa optimisme yang tinggi untuk meraih karier yang diinginkan dimasa mendatang. Pembentukan orientasi masa depan/karier tidak lepas dari beberapa faktor yang mempengaruhi, di antaranya adalah: motivasi berprestasi, peran keluarga dan lingkungan, iklim sekolah, hubungan sosial dan resiliensi. Dengan demikian, penelitian Eny menunjukkan bahwa terdapat hubungan positif yang signifikan antara efektivitas bimbingan belajar dan orientasi masa depan terhadap pengambilan keputusan karier siswa pada siswa tingkat SMA khususnya di kabupaten Klaten Jawa Tengah (Setiyowati, 2015).

Menurut George dan Cristiani (1990) keterampilan dalam menentukan keputusan merupakan suatu hal yang dapat dipelajari dan berkembang secara sistematis. Oleh karena itu para praktisi dan akademisi dapat merumuskan atau mengembangkan program-program pengembangan karier individu dalam layanan bimbingan dan konseling sebagai media belajar siswa dalam memahami karier. Sama halnya dengan George, O’Brien dkk. mendukung terbentuknya program pengembangan karier yang dapat meningkatkan eksplorasi karier individu sehingga dapat meningkatkan rasa percaya diri seseorang. Proses yang dilakukan dalam membuat keputusan karier antara lain mencari tahu informasi karier, menyeleksi pilihan karier, dan menerapkan pilihan karier yang diambil. (O’Brien dkk., 2000)

\section{Kesimpulan}

Hasil validasi yang diperoleh untuk program bimbingan dan konseling karier yang telah dibuat dari kegiatan FGD (Focus Group Discussion), memadai untuk meningkatkan kematangan karier peserta didik agar mereka tidak bingung dalam membuat rencana dan mengambil keputusan. Program bimbingan dan konseling karier ini mampu membentuk profil kematangan karier yang seharusnya dimiliki oleh peserta didik level SMA/SMK. Delapan dari sepuluh peserta didik berada pada kategori kematangan karier tinggi setelah mengikuti program bimbingan konseling karier sebanyak tiga sesi. Sesi pertama yaitu tentang pengenalan diri, sesi kedua orientasi karier dan sesi ketiga perencanaan karier. Penelitian ini merekomendasikan Guru BK di level SMA sederajat dapat 
mengimplementasikan program BK karier disekolahnya, selain itu mampu membuat rekomendasi persiapan karier siswa berdasarkan program bimbingan dan konseling karier yang telah dirancang. Adapun hasil olah data statistik menunjukkan nilai sig. 0.000 lebih kecil dari 0.05 pada taraf signifikansi 5\% maka $\mathrm{H}_{0}$ ditolak dan $\mathrm{H}_{\mathrm{a}}$ diterima, hal ini membuktikan bahwa program Bimbingan dan Konseling Karier mampu meningkatkan kematangan karier yang secara tidak langsung berkontribusi menekan angka pengangguran. Peneliti selanjutnya dapat mendalami penelitian BK karier di masingmasing jenis satuan seperti di SMA, SMK, Madrasah Aliyah (MA), Pesantren setingkat SMA juga pada jenjang Perguruan Tinggi untuk lebih mematangkan pengambilan keputusan karier agar angka pengangguran dapat ditekan.

\section{Ucapan Terima Kasih}

Penelitian ini didukung oleh hibah penelitian DIKTI dengan skema Penelitian Dosen Pemula (PDP) Tahun Anggaran 2020.

\section{Daftar Pustaka}

Adioetomo, S. M., \& Samosir, O. B. (2010). Dasar-dasar demografi. Salemba Empat. Adiputra, S. (2015). Penggunaan Teknik Modeling Terhadap Perencanaan Karir Siswa. Jurnal Fokus Konseling, 1(1).

Afdal, A., Suya, M., Syamsu, S., \& Uman, U. (2014). Bimbingan karir kolaboratif dalam pemantapan perencanaan karir siswa SMA. Jurnal Konseling Dan Pendidikan, 2(3), $1-7$.

Crites, John 0. (1976). A comprehensive model of career development in early adulthood. Journal of Vocational Behavior, 9(1), 105-118.

George, R. L., \& Cristiani, T. S. (1990). Counseling theory and practice (3rd ed.). Allyn and Bacon.

Gunawan, Y. R. (2017). Pengaruh Hubungan Teman Sebaya dan Kondisi Sosial Ekonomi Keluarga Terhadap Orientasi Karir. Indonesian Journal of Guidance and Counseling: Theory and Application, 6(2), 21-26.

Hartinah, G., \& Wibowo, M. E. (2015). Pengembangan model layanan informasi karir berbasis life skills untuk meningkatkan pemahaman dalam perencanaan karir siswa sma. Jurnal Bimbingan Konseling, 4(1).

Hidayati, R. (2015). Layanan Informasi karir membantu peserta didik dalam meningkatkan pemahaman karir. Jurnal Konseling GUSJIGANG, 1(1).

Hurlock, E. (2010). Psikologi Perkembangan: Suatu Pendekatan Sepanjang. Rentang Kehidupan. Erlangga.

Intani, F. S., \& Surjaningrum, E. R. (2010). Coping strategy pada mahasiswa salah jurusan. Jurnal Insan Media Psikologi, 12(2).

Istirahayu, I., Mayasari, D., Fitriyadi, S., \& Damayanti, Z. (2018). Bimbingan Karir Terhadap Pemilihan Studi Lanjut Siswa Kelas XII. Jurnal Bimbingan Dan Konseling Terapan, 2(2), 139-144.

Kadiyono, A. L. (2014). Efektivitas Pengembangan Potensi Diri dan Orientasi Wirausaha dalam Meningkatkan Sikap Wirausaha. JIP (Jurnal Intervensi Psikologi, 6(1), 25-38. 
Kencana, M. R. B. (2020, Mei 8). Fakta Angka Pengangguran di Indonesia, Cenderung Turun Sebelum Corona Menghadang. Liputan 6. https://www.liputan6.com/bisnis/read/4248148/fakta-angka-pengangguran-diindonesia-condong-turun-sebelum-corona-menghadang

Moleong, L. J. (2005). Metodologi Penelitian Kualitatif. PT Remaja Rosdakarya.

Nurmi, J.-E. (1987). Age, sex, social class, and quality of family interaction as determinants of adolescents' future orientation: A developmental task interpretation. Adolescence, 22(88), 977.

O’Brien, K. M., Bikos, L. H., Epstein, K. L., Flores, L. Y., Dukstein, R. D., \& Kamatuka, N. A. (2000). Enhancing the career decision-making self-efficacy of upward bound students. Journal of Career Development, 26(4), 277-293.

Rohmawati, N. (2019). Kemandirian Siswa dalam Merencanakan Karir Ditinjau dari Persepsi Siswa Tentang Pelaksanaan Layanan Bimbingan Karir. Indonesian Journal of Guidance and Counseling: Theory and Application, 8(2), 67-73.

Setiyowati, E. (2015). Hubungan efektivitas bimbingan karir dan orientasi masa depan dengan keputusan karir remaja [PhD Thesis.]. Universitas Muhammadiyah Surakarta.

Sugiyono. (2014). Metode Penelitian Kuantitatif, Kualitatif dan R\&D. CV Alfabeta.

Sukardi, K. D. (1987). Bimbingan Karier di Sekolah-sekolah. Ghalia.

Yumnah, S. (2016). Kecerdasan Anak Dalam Pengenalan Potensi Diri. Jurnal Studi Islam, 11(2), 22-34. 